\title{
HISTORY \\ The place and the person: Named buildings, rooms and places on the campus of the Faculty of Health Sciences, University of Cape Town
}

David M Dent, Gonda Perez

The University of Cape Town's Faculty of Health Sciences, in its hundredth year, carries a strong current of its development in the inscriptions on its pediments, doorways and notice boards. These names describe the Faculty in each of its stages of evolution, and evoke a rich history. The named look down from their portraits with pride at the passing students, the staff, and the flourishing Faculty.

S Afr Med J 2012;102(6):396-399.

\section{The Wernher \& Beit Complex}

The Wernher \& Beit complex constitutes the oldest named buildings on the University of Cape Town (UCT) Medical Campus, and remains the central core of the Faculty of Health Sciences. In 1925 the Governor General, the Earl of Athlone, laid the foundation stone of the first building, which was to house pathology, bacteriology and the Dean's office. Clinical departments followed later. The subsequent adjacent building was the home of anatomy and physiology, previously located on the Hiddingh campus. The two stately buildings made up the entire Medical School, and the adjacent university-owned land lay vacant until 1938 when Groote Schuur Hospital (GSH), the teaching hospital, was finally completed.

Sir Julius Charles Wernher, 1st Baronet $\left(1850\right.$ - 1912), ${ }^{1}$ was a German-born Randlord and an art collector, who built a fortune in the diamond mines of Kimberley. He returned to London where he continued to develop his business interests and developed a passion

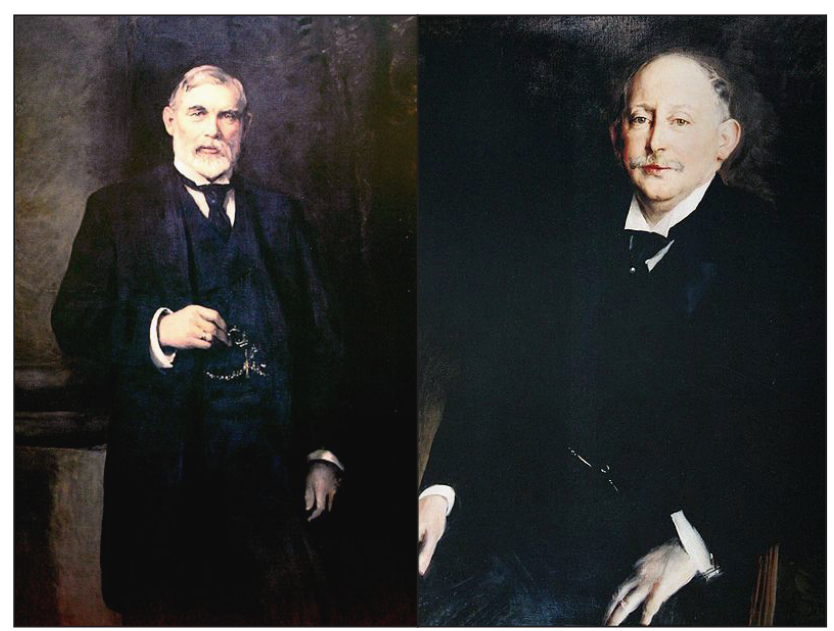

Sir Julius Charles Wernher and Alfred Beit.

David M Dent is Emeritus Professor of Surgery in the Faculty of Health Sciences, University of Cape Town. Gonda Perez is Deputy Dean of the Faculty of Health Sciences, University of Cape Town. for collecting art. At the time of his death he was one of the richest men in the UK with a then fortune of $£ 11$ million (R142 million).

Alfred Beit $(1853-1906)^{2}$ was born in Hamburg and emigrated to the Cape Colony in 1875 during the 'diamond rush' at Kimberley. He became one of a group of financiers who gained control of the diamond-mining claims in the Central, Du Toitspan, and De Beers mines, becoming life-governor of De Beers. With Cecil Rhodes, he financed the disastrous Jameson Raid of late 1895. On his death in 1906, the Beit Trust was formed, large sums of money being bequeathed for university education and research in South Africa, Rhodesia, Britain and Germany. One bequest was for the establishment of an educational institution in Johannesburg, provided the money was used within 10 years. Fortunately for UCT, dragging of feet to the north led to the non-utilisation of the bequest. General Smuts, then Minister of Education, went to London and visited deceased Alfred's brother Otto, together with the invited Julius Wernher, and persuaded them to establish a Medical School on the Rhodes estate in Cape Town.

\section{The Wolfson Pavilion}

The Wernher \& Beit complex underwent extensive renovations in 2004 - 2006, architects Gabriel Fagan and Associates winning an award for their work. They linked the north and south buildings, renovated and expanded them. The spacious glass-clad link building is called the Wolfson Pavilion. The whole complex was named the Institute of Infectious Disease and Molecular Medicine (IIDMM). Much of the generous funding came from the Wolfson Foundation.

Sir Leonard Gordon Wolfson, 1st Baron Wolfson (1927 - 2010), ${ }^{3}$ was a British businessman, and son of Great Universal Stores magnate Sir Isaac Wolfson, 1st Baronet. He was Chairman of the Wolfson Foundation and was raised to the peerage as Baron Wolfson of Marylebone in 1985. In much he followed in the footsteps of his father, Isaac, of whom Lord Young of Graffham once said: 'He loved making money, and he loved giving it away.'

\section{The Barnard Fuller Building}

The administrative offices and office of the Dean reside in this building, as well as a refectory and certain named rooms (see below), a squash court and various offices.

E Barnard Fuller ${ }^{4,5}$ played a key role in developing the UCT Medical School facilities when the university was still known as the South African College, and later, when it became the University of Cape Town. Educated at the South African College, he went on to qualify as a doctor at Edinburgh University, graduating with first class honours in 1891, returning to Cape Town in 1892. In 1907, 


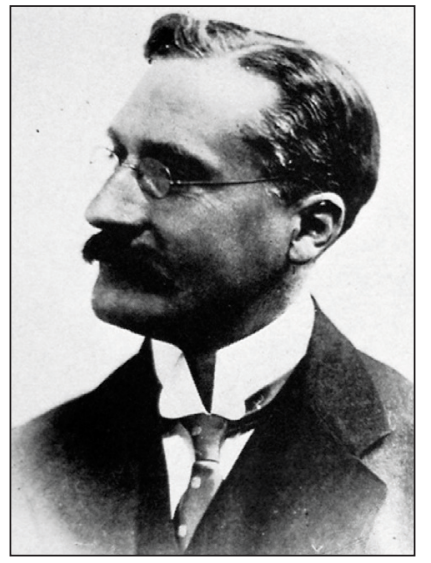

E Barnard Fuller.

Fuller said: 'Looking into the future, I see before me as in a vision a great teaching University arising under the shadow of old Table Mountain and a part of that University is composed of a well-equipped Medical School.' He helped fulfil this vision and grow the Medical School, campaigning for the Union Government to fund chairs in anatomy, physiology and other fields from 1910. His contributions to the formation of the Medical School continued tirelessly. He became President of Convocation and Chairman both of Senate and University Council. In 1940 UCT conferred an honorary Doctorate of Laws upon him.

\section{The Jolly Lecture Theatre}

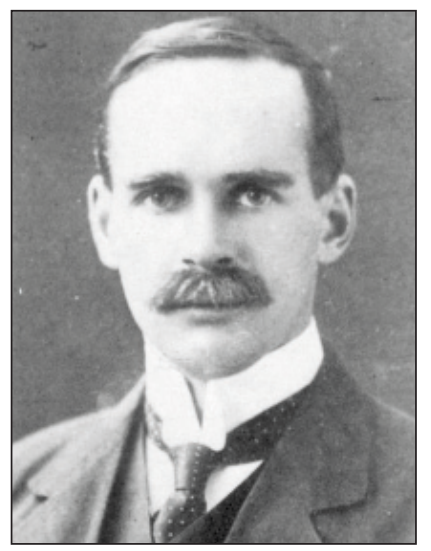

William Tasker Adam Jolly.

The first Physiology Lecture Theatre was situated in the Anatomy and Physiology Building on the Hiddingh campus in the Company Gardens, and in 1929 this was relocated to the new Wernher \& Beit buildings on the Rhodes Estate. In 1938 it was named the Jolly Lecture Theatre after the death of William Jolly, much admired Professor of Physiology. Extensive renovations of the original building complexes in 2005 led to the transfer of his name to the last intact historical lecture theatre, which has been restored to its original form and carries this cheerful name.

William Tasker Adam Jolly, DSc, LLD (Hon Ed), ${ }^{6}$ was the first (1911) Professor of Physiology at UCT, and in South Africa. He was Dean of the Medical Faculty from 1918 to 1931. In 1920 he established the Students Medical Society (later Medical Students Council, then the Health Sciences Students Council), and he also founded the Medical Library. He was President of the British Medical Association (Cape Western Branch). He published extensively, and was called the father of medical research in South Africa'. He gained an international reputation for his research into the electrical activity of the heart, and made a major contribution to the development of the electrocardiograph (ECG) machine.

\section{The Falconer Lecture Theatre}

The Falconer Lecture Theatre is located on the J (previously E) floor of the old GSH building. It is a classic wooden horseshoe of seats which have been occupied by generations of clinical students, who leaned forward to see signs demonstrated on patients, or dozed back during didactic lectures.

Arthur Wellesley Falconer, ${ }^{7}$ an Aberdeen graduate, was appointed as the first Professor of Medicine in 1919, a position he held until 1938 when he became Principal and Vice-Chancellor of the University. At this time UCT was the only university offering a medical degree in the country. Black students were officially allowed to enrol for the first time during his tenure as Vice-Chancellor and Principal, and the first admissions followed from 1940. He retired in 1947. Known as 'Oubaas' by the students, he was enormously popular, and was called one of the 'Big Three', the other 2 being Charles Saint (surgery) and Cuthbert Creighton (obstetrics and gynaecology). On his retirement the Chair of Medicine was divided in two, to be occupied by J F Brock and F Forman, who then taught in the newly built GSH, where the lecture theatre resides.

\section{The J S Marais \\ Laboratory}

The J S Marais Laboratory is located between the Chris Barnard Building and the Academic Mortuary. It is now the Pathology Teaching Laboratory of the Clinical Laboratory Sciences Department.

The Jacobus Stephanus Marais ${ }^{6}$ Memorial Research Fund was bequeathed in 1934 for 'research work in surgery', through the good offices and influence of his medical nephew Dr D H Pheiffer. The money was used initially for scholarships, but subsequently to build the J S Marais Surgical Research Laboratory in 1958, where Chris Barnard performed his ground-breaking heart transplant research.

\section{The Chris Barnard Building}

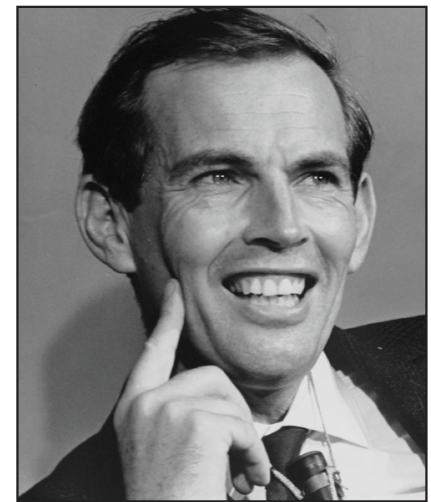

Chris Barnard.

An imposing nine-storey building occupies the northern boundary of the medical campus, and was built in consequence of the first human heart transplant, performed in 1967. Originally called the South African Mining Industry Organ Transplant (SAMIOT) Building, or Cape Heart Building, it was opened in 1973 to house all aspects of cardiac research. The name was changed to the Chris Barnard Building after Barnard's death.

Christiaan Neethling Barnard (1922 $2001)^{8}$ was born in Beaufort West, and qualified at UCT in 1945. He was fascinated by research and obtained two doctorates at UCT - 'The treatment of tuberculous meningitis' (1953), and 'The aetiology of congenital intestinal atresia' (1958). He studied cardiovascular surgery at the University of Minnesota, and returned to UCT as Head of Cardiovascular Surgery. He performed the world's first human heart transplant operation on 3 December 1967. Barnard's innovations in cardiac surgery brought him honours from a host of foreign medical societies, governments, universities, and other institutions.

\section{The Stuart Saunders Reading Room}

This attractive room is on the first floor of the Medical Library, and was previously known as 'The Doctor's Room.' Among the historically interesting contents are an oak table and chairs (bearing the inscription 
BMA) which were used in the Wale Street offices of the British Medical Association and in 1936 incorporated into the Medical Library in the Werner \& Beit Complex. The new library was completed in 1953. It is a quiet room where postgraduates come to read and work under the watchful and encouraging eye of the room-named person in the picture on the north wall.

Stuart Saunders ${ }^{9}$ is a graduate of UCT (1953), who qualified as a physician and became Professor and Head of the Department of Medicine (1971 - 1980), and then Vice-Chancellor of the University (1981 - 1997). He is co-founder of the Liver Clinic and Liver Research Unit. He holds honorary doctoral degrees from the following universities: Rhodes, Princeton, Aberdeen, Toronto, Sheffield and his alma mater, UCT. He has been a Senior Advisor to the Andrew W Mellon Foundation. He was awarded the Order of the Baobab (Silver) by the President of South Africa.

\section{The Helen Brown Reading Room}

The reference and reading room on the ground floor of the Medical Library bears a plaque, unveiled in 2003, which reads: 'Helen Annan Brown 1913 - 1999. This room commemorates the dedication and knowledge of an exceptional clinician and teacher.

Helen Brown $n^{10}$ is best remembered by generations of medical students as the inspiring physician who worked on the A floor of the old GSH, and became the head of her medical firm there. Past students will evoke her teaching rounds, always at the bedside, always teaching with the basic tenets of diagnosis by detailed history and thorough examination. The daughter of Alexander Brown, Professor of Applied Mathematics at UCT, she qualified in 1935 and spent time in the UK, serving at the Royal Postgraduate Medical School in London, and at the outbreak of the Second World War, the Blood Transfusion Service in Slough. She returned to UCT in 1942, joining the Department of Medicine, an association she held until her retirement in 1991. She opened the first blood bank at GSH, and cemented her reputation as a learned and innovative physician and teacher.

\section{The George Dall Link Bridge}

This important pedestrian bridge spans the busy Anzio Road and links the Faculty campus from the library building on one side to GSH on the other. The plaque reads: 'George Dall 1921 - 1996. This bridge symbolises the link between scholarship and service, and between the university and the community which George Dall exemplified.'

George Dall ${ }^{11}$ graduated at UCT in 1944 and was a convenor of the hospital Rag in his student days. He qualified as an orthopaedic surgeon, and became Professor of Orthopaedics (1977 - 1983), transforming a small department into an internationally recognised one, and being honoured by the award of Life Membership of the South African Orthopaedic Association and Honorary Fellowship of the British one. He became Dean of the Faculty (1984 1989), and is remembered as a man of firm conviction and unwavering and independent fairness.

\section{The I P van Niekerk Conference Centre}

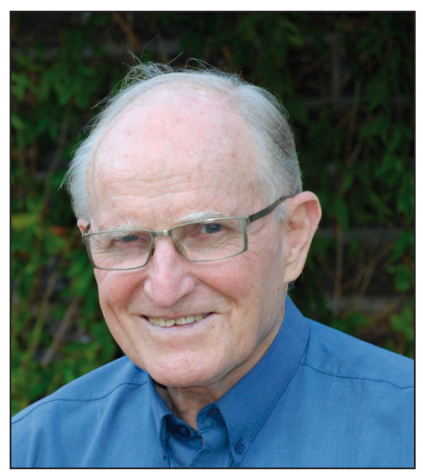

J P van Niekerk.

This complex is located within the Barnard Fuller building, and the descriptive plaque (2003) reads: 'Dedicated to Prof. J P van Niekerk, Founder, Developer and Champion of the UCT Faculty of Health Science Postgraduate Conference Division.'

Johannes Philippus ('JP') van Niekerk ${ }^{12}$ qualified at UCT in 1959, obtained the higher qualifications MD, FRCR, MMed (RadD), DIH (RCP\&S), and specialised in radiology, but his life's work was with the Faculty, where he made a major and lasting contribution. He served as the first Deputy Dean and then Dean (1990 - 1999). He was the driving force behind the construction of the Barnard Fuller Building, which grew out of a more modest initial venture to the comprehensive and invaluable structure that it is today. He was President of the South African Medical Association, long serving on the Health Professions Council (1990 -2004), member of the Executive Council of the World Federation for Medical Education and Chairman of the Hospice Palliative Care Association of South Africa (1993 - 2006). He has been the Managing Editor of the Health and Medical Publishing Group since 2000.

\section{The Basil Jaffe Room}

This room is located within the discipline of family medicine in the Falmouth building, and was so named in 2010.

Basil Jaffe $(1923-2009)^{13}$ qualified at UCT in 1946, and went into general practice latterly called family medicine - an area of healthcare in which he was to devote his life, and excel. In 1950 he was instrumental in establishing an affiliation with the Faculty of the British College of General Practice, and in 1975 he was made Fellow of the Royal College of General Practitioners. He was elected Chairman of the Faculty of General Practice of the College of Medicine of SA and in 1980 became founding chairman of the SA Academy of Family Practice/ Primary Care, subsequently becoming its President. He devoted a large part of his life to student teaching, and the promotion of family medicine. In 1997 UCT awarded him the Distinguished Family Practice Medal.

\section{The Dumo Baqwa Room}

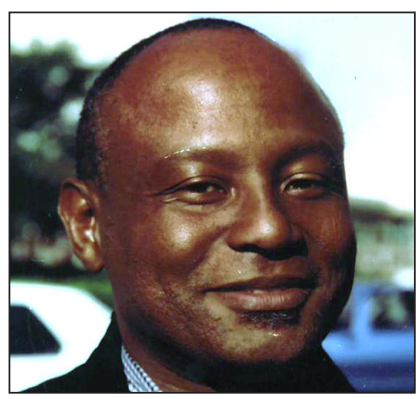

Dumo Baqwa.

This room (previously interleading Conference Rooms 1 \& 2) is located on the ground floor of the Barnard Fuller Building, and will be thus named in 2012.

Jeffrey Dumo Baqwa (1949 - 2001) ${ }^{14}$ was appointed as the first Professor of Primary Health Care in 1995, a position he held until his untimely death in 2001. He brought with him international and local experience, having worked for the World Health Organization, USAid, and the Alexandra Health Centre in Gauteng. As the first African professor appointed in the Faculty, as Associate Dean, and as warden of the Forrest Hill Residence, he served as an important role model for the students. Baqwa had been a political activist and a leader within the Black Consciousness Movement, going into exile and qualifying as a doctor in Saarland in West Germany in 1988. He became known for building partnerships within communities and providing equity within healthcare. In 2005 Archbishop Njongonkulu Ndugane delivered the first J Dumo Baqwa Inaugural Memorial Lecture in the Jameson Hall, emphasising that 


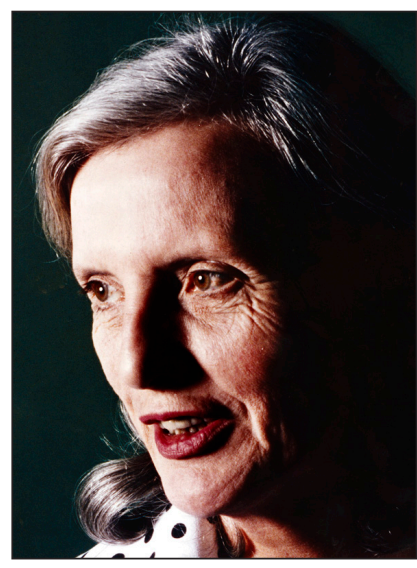

Francis Ames.

Baqwa was a primary healthcare pioneer, and concluding that 'Our leaders and role models must be beyond reproach: trustworthy, faithful, moral in every sense of the word.'

The Francis Ames Room This room (previously Conference Room 4) is located on the ground floor of the Barnard Fuller Building, and will be thus named in 2012.

Francis Ames $(1920 \text { - 2002 })^{15}$ had a distinguished career. Qualifying in 1942 with an $\mathrm{MB} \mathrm{ChB}$ degree, she subsequently became the first woman to receive a Doctorate in Medicine (UCT, 1964), and then became Head of the Department of Neurology (1976 - 1986). She outspokenly propagated the therapeutic value of cannabis and fought for its decriminalisation. An ardent human rights activist she was one of few doctors during the apartheid years willing to speak out against human rights abuses, often at great risk to her professional career. An act of singular courage as part of a group of doctors was to take the then South African Medical and Dental Council to court over its failure to discipline the doctors who allowed black consciousness leader Steve Biko to die through their neglect. The case was finally won, restoring credit to the medical profession in South Africa. She was made an Emeritus Associate Professor (1997) and was awarded the degree of Doctor of Science in Medicine (honoris causa, 2001). President Nelson Mandela conferred on her the Star of South Africa, the country's highest civilian award.

\section{The Aadil Moerat Room}

This room (previously Conference Room 3) is located on the ground floor of the Barnard Fuller Building, and will be thus named in 2012.

Aadil Moerat $(1964-1998)^{14}$ exemplifies what the University would like to see in its medical graduates in their life, work, and social contributions. While a student he participated in the Progressive Primary Care Network Emergency Services Groups, providing support and first aid training in the townships where political unrest was prevalent, and where casualties of police shooting risked arrest if seeking attention in public clinics or hospitals. He graduated in 1987 and chose to establish a surgery for patients in Guguletu, where he 'gave his all' to the people he served, becoming fondly known as 'the people's doctor'. He was shot dead in his surgery at the age of 34 by robbers on 21 January 1998. The conference room reminds the students who use it of the dedication and selfless service of a young doctor.

\footnotetext{
. Wikipedia. http://en.wikipedia.org/wiki/Julius_Wernher (accessed 28 October 2011).

Louw JH. In the Shadow of Table Mountain. Cape Town: Balkema, 1968:14,18,131.

3. Obituaries. Leonard Wolfson: businessman and philanthropist. The Independent [UK]. 4 June 2010.

The Independent [UK]. 4 June 2010.

5. Louw JH. In the Shadow of Table Mountain. Cape Town Louw JH. In the Shdo

Balkema, 1968:55-61.
6. Digby A, Phillips H. At the Heart of Healing: Groote Schuur Hospital 1938 - 2008. Johannesburg: Jacana Media, 2008:276.

7. University of Cape Town. http://www.uct.ac.za/about/intro/ history/timeline/research/ (accessed 15 October 2011).

8. Wikipedia. http://www.answers.com/topic/dr-christiaan-barnard (accessed 23 October 2011).

9. Who's Who in Southern Africa. http://www.whoswhosa.co.za/ stuart-saunders-6354 (accessed 24 October 2011).

10. Health Sciences pay homage to a leading light. University of Cape Town Monday Paper. UCT Archives. Vol 22.35, 17 November 2003.

11. Obituary. George Dall. J Bone Joint Surg [Br] 1996;78-B:994.

12. Health Sciences pay homage to a leading light. University of Cape Town Monday Paper. UCT Archives. Vol. 22.38, 9 of Cape Town Mecember 2003.

13. Levenstein S. Citation on opening of the Basil Jaffe Room, 15 September 2010.

14. Jacobs M. Letter of motivation to Mr H Amoore, UCT Registrar, for the renaming of Conference Rooms 1, 2 and 3.20 May 2011. 15. London L. Letter of motivation to $\mathrm{Mr} \mathrm{H}$ Amoore, UCT Registrar, for the naming of the Francis Ames Room. 9 May 2011.
}

Accepted 6 February 2012 